dr. sc. Dragan Gabrić

Sveučilište u Mostaru, Mostar, Bosna i Hercegovina

dragan.gabric@sum.ba

\title{
TRADICIONALNI POKAZATELJI ANALIZE \\ FINANCIJSKIH IZVJEŠTAJA U FUNKCIJI \\ UTVRĐIVANJA RAČUNOVODSTVENIH \\ MANIPULACIJA U FINANCIJSKIM IZVJEŠTAJIMA \\ PODUZEĆA
}

Primljen: 6. rujna 2018.

Prihvaćen: 1. listopada 2018.

\section{Prethodno priopćenje}

\section{Sažetak}

Financijski izvještaji opće namjene predstavljaju važan izvor informacija za poslovno odlučivanje. Predmet ovog rada je istraživanje utjecaja tradicionalnih pokazatelja analiza financijskih izvještaja koji se temelje na obračunskoj osnovi na utvrđivanje računovodstvenih manipulacija u financijskim izvještajima poduzeća. Osnovni cilj ovog istraživanja je utvrditi tradicionalne pokazatelje analize financijskih izvještaja koji pozitivno utječu na utvrđivanje računovodstvenih manipulacija u financijskim izvještajima, te analizirati obilježja vrijednosti utvrđ̈enih pokazatelja s obzirom na utvrđenu razinu računovodstvenih manipulacija poduzeća u Federaciji BiH. Istraživanje je provedeno na uzorku poduzeća sa tržišta kapitala u Federaciji BiH u razdoblju od 2010. godine do 2014. godine. Prikupljeni podaci analizirani su primjenom metoda deskriptivne i inferencijalne statistike, a dobiveni rezultati su prezentirani pomoću tabličnih prikaza. Primjena parametrijskih i neparametrijskih statističkih testova je rezultirala utvrđivanjem tradicionalnih pokazatelja analize financijskih izvještaja koji se razlikuju između poduzeća sa utvrđenim računovodstvenim manipulacijama i poduzeća bez utvrđenih računovodstvenih manipulacija u financijskim izvještajima. To su koeficijent ubrzane likvidnosti (QLiq), faktor zaduženosti - broj godina (FqSol), koeficijent obrtaja ukupne imovine (QtTA), koeficijent obrtaja tekuće imovine (QtCA), trajanje naplate potraživanja (DRec), dobit po dionici (EPS) i pokazatelj odnosa zarade $i$ cijene (E/P). Rezultati istraživanja također pokazuju da poduzeća sa utvrđenim računovodstvenim manipulacijama u financijskim izvještajima imaju u prosjeku „slabije“ vrijednosti tradicionalnih pokazatelja analize financijskih izvještaja u odnosu na poduzeća bez utvrđenih računovodstvenih manipulacija 
u financijskim izvještajima. Na temelju iznesenog pokazuje se da tradicionalni pokazatelji analize financijskih izvještaja koji se temelje na obračunskoj osnovi pozitivno utječu na utvrđivanje računovodstvenih manipulacija u financijskim izvještajima poduzeća.

Ključne riječi: financijski izvještaji, računovodstvene manipulacije, tradicionalni pokazatelji analize financijskih izvještaja

JEL: M41, M42

\section{UVOD}

Financijski izvještaji u suvremenom poslovanju predstavljaju važan izvor informacija za poslovno odlučivanje. Realne i objektivne računovodstvene informacije jedan su od neophodnih preduvjeta za poslovno odlučivanje svih interesnih strana (engl. stakeholdera). „Cilj je financijskih izvještaja opće namjene pružiti informacije o financijskom položaju, financijskoj uspješnosti i novčanim tokovima poslovnog subjekta koje su korisne širokom krugu korisnika u donošenju ekonomskih odluka." (MRS 1, t. 9.). Iako računovodstveni propisi, prije svega Međunarodni standardi financijskog izvještavanja, polaze od pretpostavke da financijski izvještaji realno i objektivno prezentiraju financijski položaj, financijsku uspješnost i novčane tokove subjekata, postoji i druga krajnost koja podrazumijeva da financijski izvještaji sadrže učinke računovodstvenih manipulacija.

Istraživanja u vezi analize i ispitivanja kvalitete financijskih izvještaja, mjerene prije svega kroz pojavu i intenzitet računovodstvenih manipulacija, su uvijek aktualna. To prije svega vrijedi za američku znanstvenu i istraživačku javnost, dok „manja zastupljenost istraživanja računovodstvenih pogrešaka i manipulacija u financijskim izvještajima na europskom području proizlazi iz manje transparentnih tržišta kapitala i otpora (manjka volje) poduzeća da javno objave potpuni set financijskih izvještaja.“ (Aljinović Barač, Klepo, 2006, 274). U tom kontekstu, predmet ovog rada je analiza $\mathrm{i}$ istraživanje utjecaja tradicionalnih pokazatelja analize financijskih izvještaja koji se temelje na obračunskoj osnovi na utvrđivanje računovodstvenih manipulacija u financijskim izvještajima poduzeća. Osnovni cilj ovog istraživanja je utvrđivanje tradicionalnih pokazatelja analize financijskih izvještaja, koji se temelje na obračunskoj osnovi, koji pozitivno utječu na utvrđivanje računovodstvenih manipulacija u financijskim izvještajima. Drugim riječima, cilj je utvrditi i analizirati obilježja utvrđenih tradicionalnih pokazatelja analize financijskih izvještaja poduzeća u Federaciji BiH a koji su rezultat računovodstvenih manipulacija kod poduzeća sa utvrđenim manipulacijama. Također, cilj je istražiti da li postoje značajne razlike kod određenih pokazatelja koji se mogu iskoristiti za utvrđivanje računovodstvenih manipulacija u financijskim 
izvještajima poduzeća. U ovom radu polazi se od pretpostavke da tradicionalni pokazatelji analize financijskih izvještaja pozitivno utječu na utvrđivanje računovodstvenih manipulacija u financijskim izvještajima poduzeća. Kroz više istraživanja, sugerira se unaprjeđenje postojećih istraživanja koji na određeni način razmatraju i dovode u vezu različite financijske i nefinancijske pokazatelje s utvrđivanjem računovodstvenih manipulacija $u$ financijskim izvještajima (Dechow et al., 2010; Bayley i Taylor, 2007; Prevoo, 2007).

\section{PREGLED PRETHODNIH ISTRAŽIVANJA I POSTAVLJANJE HIPOTEZA}

Dosadašnja istraživanja o kvaliteti financijskih izvještaja u najvećoj mjeri su se bazirala na analiziranju mjera obračunskih veličina (Jones, 1991; Dechow i Dichev, 2002), kao i istraživanju odabranih i posebno razvijenih financijskih i nefinancijskih pokazatelja te njihovom utjecaju na utvrđivanje i predviđanje računovodstvenih manipulacija (Beneish, 1999; Dechow et al., 2010). Beneish je u istraživanju iz 1997. godine analizirao financijske izvještaje 64 poduzeća sa utvrđenim računovodstvenim manipulacijama, te utvrdio da su pokazatelji ,trajanje naplate potraživanja“, te ,primarna uspješnost“ ključni za klasificiranje poduzeća u pogledu računovodstvenih manipulacija u financijskim izvještajima. U dodatnom istraživanju (Beneish, 1999) pokazano je da su pokazatelji prosječnog trajanja naplate potraživanja, indeks kretanja bruto marže, indeks kvalitete imovine, indeks kretanja prodaje i obračunske veličine, ključni faktori koje utječu na kvalitetu financijskih izvještaja. Drugi značajni model koji se temelji na financijskim i nefinancijskim pokazateljima je F-model koji je rezultat istraživanja iz 2008. godine (Dechow et al., 2010). Utvrđeno je da poduzeća s računovodstvenim manipulacijama u financijskim izvještajima imaju visoke obračunske veličine i visok udio imovine čija se nabavna vrijednost dobrim dijelom utvrđuje na temelju diskrecijske procjene uprave. Od nefinancijskih mjera, udio najmova je bio u porastu, a broj zaposlenika u značajnom opadanju kod poduzeća čiji financijski izvještaji sadrže računovodstvene manipulacije. Godine 2002. Dechow i Dichev razvili su model procjene kvalitete financijskih izvještaja na temelju kvalitete obračunskih veličina u financijskim izvještajima. Model se temelji na pretpostavci da se kvaliteta računovodstvenih informacija iz financijskih izvještaja smanjuje obrnuto proporcionalno s povećanjem računovodstvenih pogrešaka $u$ iskazivanju obračunskih veličina u financijskim izvještajima. Kao osnovna kritika na ovaj, kao i ostale modele koji se temelje na mjerenju obračunskih veličina, ističe se slaba prediktivna sposobnost.

Imajući u vidu prethodno navedeno, kao i ciljeve ovog istraživanja, može se formulirati osnovna hipoteza: 
$\mathrm{H}_{1}$ : Tradicionalni pokazatelji analize financijskih izvještaja pozitivno utječu na utvrđivanje računovodstvenih manipulacija u financijskim izvještajima poduzeća.

Podatci koji se dobiju kroz analizu financijskih izvještaja u obliku pokazatelja analize financijskih izvještaja imaju veću informacijsku vrijednost u odnosu na apsolutne iznose $u$ vezi pojedinih stavki financijskih izvještaja opće namjene. Stoga je u osnovi glavne hipoteze polazno određenje da tradicionalni pokazatelji analize financijskih izvještaja predstavljaju koristan instrument za utvrđivanje računovodstvenih manipulacija $u$ financijskim izvještajima poduzeća. S obzirom na područje istraživanja ovog rada, sasvim opravdano se može istaknuti istraživačko pitanje da li su tradicionalni pokazatelji analize financijskih izvještaja cilj ili motiv računovodstvenog manipuliranja. Međutim, to pitanje nije predmet ovog rada, odnosno izvan je teme i opsega ovog rada. Osnovni cilj je utvrditi i analizirati obilježja utvrđenih tradicionalnih pokazatelja analize financijskih izvještaja poduzeća u Federaciji BiH a koji su rezultat računovodstvenih manipulacija kod poduzeća sa utvrđenim manipulacijama. Također, cilj je istražiti da li postoje značajne razlike kod određenih tradicionalnih pokazatelja između promatranih grupa poduzeća (sa i bez računovodstvenih manipulacija) a koji zbog toga mogu biti korisni za utvrđivanje računovodstvenih manipulacija u financijskim izvještajima poduzeća. Temeljem razrade glavne hipoteze formirane su pomoćne hipoteze prilagođene potrebama empirijskog dijela istraživanja i statističkog testiranja:

$\mathrm{H}_{1 \mathrm{a}}$ : Postoji statistički značajna razlika u prosječnoj vrijednosti tradicionalnih pokazatelja analize financijskih izvještaja između poduzeća čiji financijski izvještaji sadrže računovodstvene manipulacije i poduzeća čiji financijski izvještaji ne sadrže računovodstvene manipulacije.

$\mathrm{H}_{1 \mathrm{~b}}$ : Poduzeća sa utvrđenim računovodstvenih manipulacijama u financijskim izvještajima imaju u prosjeku ,slabije“ vrijednosti tradicionalnih pokazatelja analize financijskih izvještaja u odnosu na poduzeća bez utvrđenih računovodstvenih manipulacija u financijskim izvještajima.

Naime, uloga financijskih pokazatelja u utvrđivanju određenih pojava i događaja u poslovanju je nesporna (neupitna, nedvojbena) i pokazana u prethodnom razdoblju za potrebe previđanja bankrota (Altman, 1968), ali i drugih poslovnih pojava kao što su smanjenje poslovanja ili povećanje kapitala (Korcan, Dechow, Yuan i Wang, 2013). Također, sugeriraju se dodatna istraživanja koja bi u fokusu interesa imala utjecaj financijskih pokazatelja na utvrđivanje kvalitete financijskih izvještaja poduzeća, odnosno računovodstvenih manipulacija u financijskim izvještajima poduzeća (Korcan et al., 2013; Dechow et al., 2010). Nadalje, postojeća istraživanja o povezanosti između određenih i odabranih financijskih pokazatelja i kvalitete financijskih izvještaja su većinom zastupljena u zemljama 
anglosaksonskog govornog područja (Cuzdriorean, 2013) čije se karakteristike institucionalnog okvira poslovanja značajno razlikuju u odnosu na europske i domaće uvjete. Dosadašnja istraživanja su razmatrala utjecaj posebno razvijenih ili odabranih pokazatelja analize financijskih izvještaja na kvalitetu financijskih izvještaja. Originalnost ovog istraživanja ogleda se u razmatranju odabranog cjelovitog seta tradicionalnih pokazatelja analize financijskih izvještaja utemeljenih na obračunskom načelu na utvrđivanje računovodstvenih manipulacija u financijskim izvještajima poduzeća. Može se istaknuti da je problematika ovog istraživanja aktualna i nedovoljno istražena, osobito u domaćim i regionalnim uvjetima. Osnovni doprinos ovog istraživanja je spoznaja o osnovnim područjima računovodstvenih manipulacija u financijskim izvještajima poduzeća, te spoznaja o obuhvatu i obilježjima vrijednosti tradicionalnih pokazatelja analize financijskih izvještaja koji doprinose utvrđivanju računovodstvenih manipulacija u financijskim izvještajima na uzorku poduzeća u Federaciji BiH, kako bi se unaprijedila spoznaja o razini kvalitete financijskih izvještaja, te kvaliteta postupaka utvrđivanja računovodstvenih manipulacija $u$ financijskim izvještajima poduzeća.

\section{OBLIKOVANJE MODELA ISTRAŽIVANJA}

Metodološki pristup istraživanju kvalitete financijskih izvještaja podrazumijeva načine istraživanja i analiziranja računovodstvenih manipulacija u financijskim izvještajima. S tim u vezi, moguće je identificirati tri osnovna metodološka pristupa istraživanju računovodstvenih manipulacija u financijskim izvještajima:

1. istraživanja značajnih pogrešnih prikazivanja utemeljena na obračunskim veličinama;

2. istraživanja značajnih pogrešnih prikazivanja utemeljena na financijskim i nefinancijskim pokazateljima; i

3. alternativni pristupi istraživanja značajnih pogrešnih prikazivanja.

U konkretnom slučaju, za potrebe ovog istraživanja polazi se od metodološkog pristupa utemeljenog na obračunskim veličinama. Istraživanja koja su utemeljena na obračunskim veličinama su dominantna istraživanja. Prva istraživanja u vezi kvalitete financijskih izvještaja, manipulacija i značajnih pogrešnih prikazivanja u financijskim izvještajima su provedena na osnovu promjena u obračunskim veličinama ${ }^{1}$. Također, kasnija testiranja postojećih modela, kao i razvoj novih

Prema obračunskom načelu računovodstvene kategorije, odnosno elementi financijskih izvještaja se priznaju u trenutku nastanka događaja, neovisno o tome kada će uslijediti primitak ili izdatak novca po tome osnovu. Ukupne obračunske veličine u financijskim izvještajima jednog poduzeća mogu se definirati kao razlika između dobiti od poslovnih aktivnosti i novčanog toka iz poslovnih aktivnosti. Ovaj način izračuna ukupnih obračunskih veličina poznat je kao pristup utemeljen na novčanim tokovima. Alternativno, ukupne obračunske veličine mogu se 
modela utemeljena su na obračunskim veličinama. Može se istaknuti da su obračunske veličine i danas aktualna osnova istraživanja računovodstvenih manipulacija u financijskim izvještajima. „Razumijevanje računovodstvenih manipulacija tiče se jednog od centralnih pitanja u računovodstvu, a to je utjecaj i važnost obračunskih veličina u formiranju agregatne mjere uspješnosti poslovanja poduzeća.“ (Schipper, 1989). Informativna vrijednost obračunskih veličina potvrđena je u različitim empirijskim istraživanjima (Sloan, 1996; Richardson et. al., 2006). Obračunske veličine mogu biti izvorom relevantnih indikatora koji mogu doprijeti utvrđivanju računovodstvenih manipulacija.

Međutim, ovdje se ne radi o klasičnom pristupu koji uzima u obzir ukupan iznos obračunskih veličina na razini financijskih izvještaja, već o modificiranom pristupu koji razmatra odnose između pojedinih stavki financijskih izvještaja, odnosno tradicionalnih pokazatelja analize financijskih izvještaja. Jedan od osnovnih ciljeva ovog istraživanja je je utvrđivanje tradicionalnih pokazatelja analize financijskih izvještaja koji pozitivno utječu na utvrđivanje računovodstvenih manipulacija u financijskim izvještajima, te analiza obilježja vrijednosti utvrđenih pokazatelja s obzirom na razinu utvrđenih računovodstvenih manipulacija. U razvoju modela istraživanja polazi od pretpostavke da su tradicionalni pokazatelji analize financijskih izvještaja u funkciji utvrđivanja računovodstvenih manipulacija u financijskim izvještajima poduzeća. Model istraživanja može se predstaviti u obliku funkcije.

$$
\begin{aligned}
& \mathbf{M M}_{\mathrm{i}, \mathrm{t}}=\beta_{0 \mathrm{i}, \mathrm{t}}+\beta_{1} \mathrm{Qliq}_{\mathrm{i}, \mathrm{t}}+\beta_{2} \mathrm{Fliq}_{\mathrm{i}, \mathrm{t}}+\beta_{3} \mathrm{Cliq}_{\mathrm{i}, \mathrm{t}}+\beta_{4} \mathrm{FSt}_{\mathrm{i}, \mathrm{t}} \\
& +\beta_{5} \mathrm{QSol}_{\mathrm{i}, \mathrm{t}}+\beta_{6} \mathrm{QCap}_{\mathrm{i}, \mathrm{t}}+\beta_{7} \mathrm{LibCap}_{\mathrm{i}, \mathrm{t}}+\beta_{8} \mathrm{FqSOl}_{\mathrm{i}, \mathrm{t}}+\beta_{9} \operatorname{CovInt}_{\mathrm{i}, \mathrm{t}} \\
& +\beta_{10} \operatorname{QtTA}_{\mathrm{i}, \mathrm{t}}+\beta_{11} \mathrm{QtCA}_{\mathrm{i}, \mathrm{t}}+\beta_{12} \mathrm{QtRec}_{\mathrm{i}, \mathrm{t}}+\beta_{13} \mathrm{QtInv}_{\mathrm{i}, \mathrm{t}}+\beta_{14} \mathrm{DRec}_{\mathrm{i}, \mathrm{t}}+\beta_{15} \operatorname{DInv}_{\mathrm{i}, \mathrm{t}} \\
& +\beta_{16} \operatorname{NmProf}_{i, t}+\beta_{17} \text { BmProf }_{i, t}+\beta_{18} \operatorname{NmTA}_{i, t}+\beta_{19} \text { BmTA }_{i, t}+\beta_{20} \operatorname{NmCap}_{i, t} \\
& +\beta_{21} \mathrm{Tec}_{\mathrm{i}, \mathrm{t}}+\beta_{22} \mathrm{Sec}_{\mathrm{i}, \mathrm{t}}+\beta_{23} \mathrm{Fec}_{\mathrm{i}, \mathrm{t}} \\
& +\beta_{24} \text { EPS }_{\mathrm{i}, \mathrm{t}}+\beta_{25} \mathrm{DPS}_{\mathrm{i}, \mathrm{t}}+\beta_{26} \mathrm{P} / \mathrm{E}_{\mathrm{i}, \mathrm{t}}+\beta_{27} \mathrm{D} / \mathrm{EPS}_{\mathrm{i}, \mathrm{t}}+\beta_{28} \mathrm{E} / \mathrm{P}_{\mathrm{i}, \mathrm{t}}+\beta_{29} \mathrm{D} / \mathrm{PPS}_{\mathrm{i}, \mathrm{t}}+\varepsilon_{\mathrm{i}, \mathrm{t}}
\end{aligned}
$$

gdje je

$\begin{array}{cll}\text { MM } & - & \text { Računovodstvene manipulacije u financijskim izvještajima } \\ \boldsymbol{\beta}_{0, \ldots . .,} \boldsymbol{\beta}_{\mathrm{n}} & - & \text { Parametri (koeficijenti) uz nezavisne varijable } \\ \boldsymbol{\varepsilon}_{\mathrm{i}, \mathrm{t}} & - & \text { Statistička (slučajna) pogreška } \\ \mathbf{i}, \mathbf{t} & - & \text { za poduzeće } i, \mathrm{u} \text { razdoblju } t\end{array}$

Pristup pojmovnom određenju računovodstvenih manipulacija obično podrazumijeva definiranje istih kao računovodstvenih postupaka i aktivnosti koje 
rezultiraju značajnim pogreškama ili prijevarama u financijskim izvještajima. „Računovodstveno manipuliranje nastaje kada menadžeri koriste prosudbu u procesu financijskog izvještavanja i strukturiranju transakcija te na taj način modificiraju financijske izvještaje s ciljem pogrešnog informiranja korisnika ili s ciljem utjecaja na ugovorne ishode koji ovise o računovodstvenim informacijama." (Healy i Whalen, 1999, 368). Prema Ronenu i Yaariju (2008) računovodstveno manipuliranje javlja se kao posljedica poduzimanja proizvodno / investicijskih akcija prije nego što su zarade realizirane ili izbora računovodstvenih politika kojima se utječe na računovodstvene zarade i njihovu interpretaciju nakon što su stvarne zarade realizirane. Schipper $(1989,2)$ primjerice definira računovodstvene manipulacije kao svrsishodne intervencije u eksternom financijskom izvještavanju s namjerom pribavljanja nekih privatnih koristi." (citirano prema Aljinović Barač, Klepo, 2006, 275). „U većini slučajeva, računovodstvene manipulacije se mogu definirati kao poduzimanje oportunističkih računovodstvenih procjena iznosa s namjerom pogrešnog informiranja korisnika financijskih izvještaja.“ (Aljinović Barač, Klepo, 2006, 275). Gulin (2002, pp. 34) ističe da iako pojam „manipulacije“ izaziva negativne konotacije povezane s nezakonitim aktivnostima, nisu sve manipulacije u pravilu nezakonite. U većini situacija manipulacije podrazumijevaju aktivnosti i učinke tih aktivnosti koje su u okviru zakona, dok prijevare u financijskim izvještajima podrazumijevaju poduzimanje aktivnosti koje su izvan zakonskih normi (vidjeti Dechow i Skinner, 2000). Prema Aljinović Barać i Klepo $(2006,275)$,računovodstvene manipulacije se u pravilu mogu definirati kao manipuliranje računovodstvenim brojevima koje nije u skladu s načelima istinitog i fer prezentiranja." Prema Međunarodnim standardima financijskog izvještavanja (MSFI) računovodstvene manipulacije podrazumijevaju financijske izvještaje koji sadrže značajna pogrešna prikazivanja, odnosno materijalno značajne pogreške. „Pogreška je značajna ako može, pojedinačno ili skupno, utjecati na ekonomske odluke koje korisnici donose na osnovi financijskih izvještaja. Značajnost ovisi o kombinaciji veličine i vrste izostavljene ili pogrešno prikazane stavke financijskih izvještaja." (MRS-u 8 , t. 5). Računovodstvene manipulacije u financijskim izvještajima mogu nastati u vezi s priznavanjem, mjerenjem, prezentiranjem ili objavljivanjem elemenata financijskih izvještaja. Razloge za nastanak pogrešaka treba tražiti u nedostatku informacija, pogrešnoj procjeni određenog poslovnog događaja ili financijskog učinka transakcije, neznanja, ili u konačnici, namjeri za pogrešno prikazivanje, što implicira prijevarno financijsko izvještavanje. Za potrebe ovog istraživanja računovodstvene manipulacije podrazumijevaju financijske izvještaje koji sadrže utvrđene značajne pogreške ili prijevare. Prema MRevS-u 240 (t. 4) ,pogrešno prikazivanje u financijskim izvještajima može nastati zbog prijevare ili pogreške, a ključni čimbenik za razlikovanje prijevare od pogreške jest je li namjerna ili nenamjerna ona posljedična aktivnost koja rezultira pogrešnim prikazivanjem financijskih izvještaja.“. 
Ovako koncipiran model istraživanja podrazumijeva da su u funkciji utvrđivanja računovodstvenih manipulacija u financijskim izvještajima poduzeća tradicionalni pokazatelji analize financijskih izvještaja, odnosno šest osnovnih skupina pokazatelja analize financijskih izvještaja, i to (klasifikacija prema Žageru et. al., 2008): pokazatelji likvidnosti (1), pokazatelji zaduženosti (2), pokazatelji aktivnosti (3), pokazatelji profitabilnosti (4), pokazatelji ekonomičnosti (5) i pokazatelji investiranja (6). Navedena klasifikacija autora Žagera et al. (2008, 240) podrazumijeva podjelu pokazatelja analize i prema većini drugih autora: Belak (1995, 63), Warren et al. (2012, 779), Elliot i Elliot (2011, 787), Gibson (2011, 187), Vidučić (2008, 382). Stoga je predmetna klasifikacija (Žager et al., 2008) prihvatljiva za potrebe ovog istraživanja, te se stoga djelomično modificirana uzima kao referentna klasifikacija tradicionalnih pokazatelja analize financijskih izvještaja utemeljenih na obračunskoj osnovu i u ovom radu. Svaka od navedenih skupina pokazatelja analize financijskih izvještaja koje su relevantne za ovo istraživanje obuhvaća određeni broj pojedinačnih pokazatelja. Načini izračuna odabranih pokazatelja analize financijskih izvještaja su predstavljeni kao omjeri pojedinih pozicija određenih financijskih izvještaja (ratio analiza) (Žager et al., 2008, 243-285). U analitičkom prikazu konceptualnog modela ovog istraživanja identificirano je ukupno 29 tradicionalnih pokazatelja analize financijskih izvještaja (vidjeti Prilog 1.). Analiza putem pokazatelja uključuje ispitivanje i procesiranje financijskih informacija kako bi se dobile nove, specifične informacije, dok interpretacija ima za cilj determinirati uzroke i posljedice rezultata dobivenih analizom.” (Jooste, 2005, 53). Prema Horriganu $(1965,560)$,postojanje mnoštva pokazatelja i njihova međuovisnost je i blagoslov i prokletstvo za analizu putem pokazatelja. To znači da je dovoljno tek nekoliko financijskih pokazatelja da osiguraju sve potrebne informacije, ali to istovremeno znači da je tih nekoliko pokazatelja potrebno vrlo pozorno odabrati." Međutim, jedna od najvažnijih klasifikacija financijskih pokazatelja jest ona koja razlikuje:

- tradicionalne pokazatelje analize financijskih izvještaja koji se temelje na obračunskom načelu nastanka događaja, koji ulazne informacije za analizu koriste prije svega iz bilance stanja i bilance uspjeha, $i$

- novčane pokazatelje analize financijskih izvještaja koji se temelje na načelu blagajne, koji ulazne informacije za analizu koriste, prije svega iz izvještaja o novčanim tokovima poduzeća.

Između ove dvije skupine pokazatelja postoji razlika koja proizlazi iz činjenice da računovodstvena dobit nije isto što i neto novčani tok, odnosno stanje novca i novčanih ekvivalenata, te da profitabilna poduzeća ne moraju biti ujedno i likvidna. U novije vrijeme sve više se kritizira upotreba pokazatelja kao analitičke tehnike, dijelom zbog pojave računovodstvenih manipulacija koje iskrivljuju vrijednosti dobivenih pokazatelja, a dijelom zbog problema odabira odgovarajućih 
pokazatelja. "Teoretičari degradiraju snagu pokazatelja koje praktičari koriste, argumentirajući njihov odabir i adekvatnost pravilom palca." (Altman, 2002, 8). Ipak, u ovom istraživanju polazi se upravo od teze da tradicionalni pokazatelji analize financijskih izvještaja koji se temelje na obračunskoj osnovi pozitivno utječu na utvrđivanje da li financijski izvještaji sadrže računovodstvene manipulacije ili ne.

\section{METODOLOGIJA ISTRAŽIVANJA}

\subsection{Uzorak istraživanja}

Za potrebe empirijskog dijela ovog istraživanja definiran je uzorak poduzeća $\mathrm{s}$ osnovnom i kontrolnom skupinom poduzeća. U osnovnu skupinu uzorka uključena su poduzeća čiji su financijski izvještaji sadržavali računovodstvene manipulacije, dok su u kontrolnu skupinu uzorka uključena sva ostala poduzeća čiji financijski izvještaji nisu sadržavali značajna pogrešna prikazivanja. Osnovnu i kontrolnu skupinu uzorka (vidjeti Tablicu 1.) čine revidirani godišnji financijski izvještaji poduzeća čiji su vlasnički vrijednosni papiri (dionice) uvršteni na organiziranom tržištu kapitala u Federaciji Bosne i Hercegovine (Sarajevska burza dalje: SASE). U uzorak je uključena ukupna populacija poduzeća čiji vrijednosni papiri kotiraju na Sarajevskoj burzi, a koju za potrebe ovog istraživanja čine svi emitenti čiji su vrijednosni papiri uvršteni na segmente kotacije poduzeća (jedan emitent), primarnog slobodnog tržišta (29 poduzeća) i sekundarnog slobodnog tržišta (178 poduzeća), što čini populaciju od ukupno 208 poduzeća. Iz ukupnog uzorka isključena su poduzeća čiji vrijednosni papiri nisu aktivni, kao i financijske institucije zbog institucionalnih specifičnosti poslovanja.

Tablica 1. Projektiranje uzorka istraživanja

\begin{tabular}{|l|c|}
\hline \multicolumn{1}{|c|}{ Opis } & Broj \\
\hline $\begin{array}{l}\text { Ukupan broj poduzeća na kotaciji, slobodnom primarnom i sekundarnom } \\
\text { tržištu na sarajevskoj burzi }\end{array}$ & 208 \\
\hline Neaktivna poduzeća čijim se dionicama ne trguje (suspenzija i drugo) & $(12)$ \\
\hline Financijski subjekti i institucije & $(21)$ \\
\hline UKUPNO broj poduzeća u populaciji & 175 \\
\hline $\begin{array}{l}\text { Poduzeća za koja nisu bili dostupni izvještaji o neovisnoj reviziji sa godiš- } \\
\text { njim financijskim izvještajima }\end{array}$ & $(58)$ \\
\hline UKUPNO broj poduzeća uključenih u uzorak & 117 \\
\hline
\end{tabular}

Izvor: vlastita izrada autora temeljem podataka sa Sarajevske burze 
Konačno, u uzorak je uključeno 117 poduzeća ili 66,86\% od ukupno odabrane populacije u promatranom razdoblju. Budući da su za neka poduzeća prikupljeni revidirani godišnji financijski izvještaji za jednu godinu, a za neke za više godina, onda je ukupan broj revidiranih godišnjih financijskih izvještaja koji su uključeni u konačni uzorak (osnovna i kontrolna skupina) 257 jedinica, što čini 29,37\% od ukupne populacije, što je pokazatelj koji je na zadovoljavajućoj i prihvatljivoj razini. Kada se govori o vremenskoj definiciji uzorka i kontrolnog uzorka za potrebe ovog istraživanja, u uzorak su uključena poduzeća čiji su vlasnički vrijednosni papiri uvršteni na organizirano tržište kapitala, odnosno segmente kotacije emitenata, primarnog i sekundarnog slobodnog tržišta Sarajevske burze, u petogodišnjem razdoblju od 2010. godine do 2014. godine.

U pogledu obilježja poduzeća uključenih u uzorak interesantno je promotriti strukturu uzorka s obzirom na vlasničku strukturu, klasifikaciju ${ }^{2}$ i veličinu poduzeća. Deskriptivna statistika u vezi osnovnih obilježja poduzeća (vidjeti Tablicu 2.), odnosno jedinica uključenih u uzorak, omogućuje uvid u mjere centralne tendencije i varijabilnosti obilježja uzorka. U kontekstu vlasničke strukture poduzeća uključenih u uzorak, mjera dominantne vrijednosti $(\operatorname{Mod}=1,00)$ ukazuje da je najčešći oblik vlasničke strukture - privatno domaće vlasništvo. S druge strane, centralna vrijednost (medijan) dijeli uzorak na dva dijela i poprima vrijednost 1,00 , što znači da više od $50 \%$ poduzeća uključenih u uzorak ima strukturu kapitala s privatnim domaćim vlasništvom $(72,80 \%)$. Kada se raspravlja o osnovnoj djelatnosti poduzeća uključenih u uzorak, najveći broj poduzeća se bavi prerađivačkom industrijom (Mod=2,00). S druge strane, centralna vrijednost (medijan) dijeli uzorak na dva dijela i kod obilježja djelatnosti poprima vrijednost 3,00 , što znači da više od $50 \%$ poduzeća uključenih u uzorak obavlja kao osnovnu djelatnost poljoprivredu, prerađivačku industriju ili djelatnost iz oblasti energetike.

Tablica 2. Mjerenje centralne tendencije i varijabilnosti obilježja uzorka

\begin{tabular}{|l|c|c|c|}
\hline & $\begin{array}{c}\text { Vlasnička } \\
\text { struktura }\end{array}$ & Djelatnost & $\begin{array}{c}\text { Klasifikacija } \\
\text { (veličina) }\end{array}$ \\
\hline $\mathrm{N} \quad$ Valjano & 257 & 257 & 257 \\
Sedostaje & 0 & 0 & 0 \\
Srednja vrijednost & 1,78 & 4,03 & 2,21 \\
Medijan & 1,00 & 3,00 & 2,00 \\
Mod & 1,00 & 2,00 & 2,00 \\
Standardna devijacija & 1,291 & 2,319 & 0,692 \\
\hline
\end{tabular}

Izvor: Rezultati istraživanja $(\mathrm{N}=257)$; SPSS v.20

2 Za potrebe rangiranja djelatnosti poduzeća uključenih u uzorak primijenjena su osnovna područja djelatnosti definirana kroz Klasifikaciju djelatnosti u Bosni i Hercegovini 2010, i to: poljoprivreda, prerađivačka industrija, energetika, građevinarstvo, trgovina na veliko i na malo, promet, prijevoz i skladištenje, informacije i komunikacije, usluge i ostale nespomenute djelatnosti. 
U pogledu klasifikacije, odnosno veličine poduzeća, mjera dominantne vrijednosti (Mod=2,00) ukazuje da je najveći broj poduzeća uključenih u uzorak klasificirano kao srednje veliko poduzeća. S druge strane, $84,50 \%$ poduzeća uključenih u uzorak klasificirano kao srednje veliko ili veliko poduzeća, što je logično budući da se uzorak odnosi na poduzeća sa tržišta kapitala u Federaciji BiH.

\subsection{Metode prikupljanja i obrade podataka}

Metodologija prikupljanja i obrade podataka podrazumijeva izbor odgovarajućih instrumenata prikupljanja, sistematizacije, klasifikacije i statističke obrade podataka. Podatci za potrebe empirijskog dijela istraživanja prikupljeni su primjenom tehnike analize sadržaja revizorskih i financijskih izvještaja u razdoblju od 2010. godine do 2014. godine na uzorku poduzeća čiji vrijednosni papiri kotiraju na tržištu kapitala u Federaciji Bosne i Hercegovine.

Za potrebe empirijskog dijela istraživanja u analizu su uključeni samo godišnji financijski izvještaji, budući da su ista objektom neovisne revizije financijskih izvještaja. Mjerenje zavisne varijable, odnosno računovodstvenih manipulacija u financijskim izvještajima poduzeća realizirano je primjenom sljedećih pravila:

Ukoliko je kroz neovisni revizorski izvještaj poduzeća iskazano pozitivno mišljenje bez modifikacija ili uz modifikaciju s isticanjem pitanja koja nemaju utjecaja na revizorsko mišljenje (posebni naglasci), to podrazumijeva da financijski izvještaji poduzeća ne sadrže računovodstvene manipulacije, te se zavisnoj varijabli dodjeljuje rang vrijednosti nula (0).

Ukoliko je kroz neovisni revizorski izvještaj poduzeća iskazano modificirano ${ }^{3}$ revizorsko mišljenje s isticanjem pitanja koja imaju utjecaja na revizorsko mišljenje (revizorsko mišljenje s rezervom ${ }^{4}$, suzdržavanje od revizorskog mišljenja ${ }^{5}$,

3 Cilj Međunarodnog standarda revizije (MRevS) 701 Modifikacije izvješća neovisnog revizora je utemeljiti standarde i dati upute o okolnostima u kojima izvješće neovisnog revizora treba biti modificirano, kao i o obliku i sadržaju modifikacije revizorova izvješća u tim okolnostima. Ovaj Međunarodni revizijski standard opisuje način modificiranja teksta revizorova izvješća u sljedećim situacijama:

- Pitanja koja ne utječu na revizorovo mišljenje: (a) Poseban naglasak

- Pitanja koja utječu na revizorovo mišljenje: (a) Mišljenje s rezervom, (b) Suzdržanost od mišljenja, ili (c) Negativno mišljenje.

4 Mišljenje s rezervom treba biti izraženo kada revizor zaključi da se ne može izraziti pozitivno mišljenje, ali pritom učinak neslaganja s upravom ili ograničenja djelokruga rada nije tako značajan i prevladavajući da bi zahtijevao negativno mišljenje ili suzdržanost od izražavanja mišljenja (MrevS 701, t. 12.).

5 Suzdržanost od mišljenja mora se izraziti kada je mogući učinak ograničenja djelokruga revizorova rada tako značajan i prevladavajući da revizor nije mogao prikupiti dovoljne i odgovarajuće revizijske dokaze, te stoga ne može izraziti mišljenje o financijskim izvještajima 
negativno revizorsko mišljenje ${ }^{6}$ ), to podrazumijeva da financijski izvještaji poduzeća sadrže računovodstvene manipulacije, te se zavisnoj varijabli dodjeljuje rang vrijednosti jedan (1).

Iako revizijski standardi propisuju četiri osnove vrste (stanja) revizorskih mišljenja (detaljnije vidjeti u MRevS 701 Modifikacije izvješća neovisnog revizora). Za potrebe ovog istraživanja ista su grupirana u dvije osnovne skupine s obzirom na kriterij modifikacije revizorskih mišljenja. Prva skupina su modificirana mišljenja sa isticanjem pitanja (kvalifikacija i ograda) koja utječu na kvalifikaciju revizora koje odstupa od pozitivnog mišljenja u vezi financijskih izvještaja (mišljenje s rezervom, suzdržanost od mišljenja i negativno mišljenje revizora). S druge strane je nemodificirano mišljenje bez dodatnih kvalifikacija i ograda koje podrazumijeva pozitivno mišljenje revizora o financijskim izvještajima.

Nakon toga, podatci su unijeti u bazu podataka gdje je izvršeno rangiranje varijabli, klasifikacija varijabli i izračun potrebnih pokazatelja analize financijskih izvještaja. Podatci iz revizorskih izvještaja stavljeni su u odnos s odgovarajućim podatcima iz financijskih izvještaja za određeno poduzeće i u određenom razdoblju. U konačnici su podatci pregledani, oblikovani i pripremljeni na način primjeren za unos u statistički program za statističke analize i testiranja. Za te potrebe korišten je SPSS statistički programski paket (engl. SPSS - Statistical Package for Social Sciences). Za potrebe empirijskog dijela istraživanja kao temeljni oblik znanstveno spoznajnog procesa primijenjene su statističke metode koje uključuju primjenu deskriptivne i inferencijalne statistike, a dobiveni rezultati su prezentirani pomoću tabličnih prikaza. Konkretno, za potrebe utvrđivanja tradicionalnih pokazatelja analize financijskih izvještaja koji pozitivno utječu na utvrđivanje računovodstvenih manipulacija $u$ financijskim izvještajima poduzeća primijenjen je test razlika i to parametrijski T-test. Dodatno s obzirom na to podatci iz uzorka ne slijede normalnu distribuciju, te s ciljem postizanja veće pouzdanosti rezultata istraživanja, primijenjen je i neparametrijski Man-U-Whitney test razlika.

\section{DISKUSIJA REZULTATA ISTRAŽIVANJA}

Rezultati provedenog istraživanja ukazuju na osnovna obilježja utvrđenih računovodstvenih manipulacija u financijskim izvještajima kotirajućih poduzeća $u$ Federaciji BiH. Tablica 3. pokazuje da je u 95 slučajeva (37\%) utvrđeno da financijski izvještaji poduzeća sadrže računovodstvene manipulacije. S druge strane,

(MrevS 701, t. 13.)

6 Negativno se mišljenje mora izraziti kada je učinak neslaganja toliko značajan i prevladavajući za financijske izvještaje da je revizor zaključio kako izvješće s rezervom nije primjereno za obznanjivanje da financijski izvještaji dovode u zabludu ili su nepotpuni (MrevS 701, t. 12.). 
kod 162 slučaja (63\%) nije iskazano kvalificirano revizorovo mišljenje s modifikacijama, odnosno nisu utvrđene računovodstvene manipulacije u financijskim izvještajima.

Tablica 3. Pregled područja računovodstvenih manipulacija

\begin{tabular}{|l|l|c|c|c|c|}
\hline \multicolumn{2}{|c|}{} & Broj & Postotak & $\begin{array}{c}\text { Valjani } \\
\text { postotak }\end{array}$ & $\begin{array}{c}\text { Kumulativni } \\
\text { postotak }\end{array}$ \\
\hline \multirow{5}{*}{} & Prihodi & 4 & 1,6 & 4,2 & 4,2 \\
\cline { 2 - 6 } & Amortizacija & 4 & 1,6 & 4,2 & 8,4 \\
\cline { 2 - 6 } & Rezerviranja & 7 & 2,7 & 7,4 & 15,8 \\
\cline { 2 - 6 } & $\begin{array}{l}\text { Vrijednosna usklađenja } \\
\text { potraživanja }\end{array}$ & 37 & 14,4 & 38,9 & 54,7 \\
\cline { 2 - 6 } & Umanjenje stalnih sredstava & 17 & 6,6 & 17,9 & 72,6 \\
\cline { 2 - 6 } & Revalorizacija & 5 & 1,9 & 5,3 & 77,9 \\
\cline { 2 - 6 } & Umanjenje zaliha & 9 & 3,5 & 9,5 & 87,4 \\
\cline { 2 - 6 } & $\begin{array}{l}\text { Vrednovanje stalnih sred- } \\
\text { stava }\end{array}$ & 3 & 1,2 & 3,2 & 90,5 \\
\cline { 2 - 6 } & Kapitalizacija troškova & 1 & 0,4 & 1,1 & 91,6 \\
\cline { 2 - 6 } & Financijska imovina & 6 & 2,3 & 6,3 & 97,9 \\
\cline { 2 - 6 } & Kapital & 2 & 0,8 & 2,1 & 100,0 \\
\cline { 2 - 6 } & Ukupno & 95 & 37,0 & 100,0 & \\
\hline & Nedostaje & 162 & 63,0 & & \\
\hline UKUPNO & 257 & 100,0 & & \\
\hline
\end{tabular}

Izvor: Rezultati istraživanja ( $\mathrm{N}=257)$; SPSS v.20

Rezultati istraživanja (Tablica 3.) pokazuju da se najčešća područja računovodstvenih manipulacija odnose na stavke vrijednosnih usklađenja potraživanja i umanjenja imovine ( $\mathrm{n}=63 ; 66,30 \%)$, i to: vrijednosna usklađenja potraživanja $(\mathrm{n}=37 ; 38,90 \%)$, umanjenje stalnih sredstava $(\mathrm{n}=17 ; 17,90 \%)$ i umanjenje zaliha $(n=9 ; 9,50 \%)$. Kada se govori o ostalim područjima financijskih izvještaja u vezi računovodstvenih manipulacija, ista se odnose na rezerviranja za rizike i troškove $(\mathrm{n}=7 ; 7,40 \%)$, revalorizaciju stalnih sredstava $(\mathrm{n}=5 ; 5,30 \%)$, vrednovanje financijske imovine $(n=6 ; 6,30 \%)$ i amortizaciju dugotrajne imovine $(n=4 ; 4,20 \%)$.

U pogledu obilježja računovodstvenih manipulacija, rezultati testova razlika prezentirani u Prilogu 2. pokazuju da postoji značajna razlika u prosječnom iznosu stalnih sredstava, zaliha i kratkotrajnih potraživanja između poduzeća čiji financijski sadrže računovodstvene manipulacije i poduzeća čiji financijski izvještaji ne sadrže računovodstvene manipulacije, na razini signifikantnosti od $1 \%(\mathrm{p}<0,01)$. Nadalje, prosječni knjigovodstveni iznos stalnih sredstava, zaliha i kratkotrajnih potraživanja je manji kod poduzeća čiji financijski izvještaji ne sadrže računovodstvene manipulacije u odnosu na poduzeća čiji financijski izvještaji sadrže računovodstvene manipulacije (vidjeti Prilog 2.). Prethodno navedeno ukazuje da 
je glavni izvor računovodstvenih manipulacija u financijskim izvještajima poduzeća u Federaciji BiH nepriznavanje (rashoda) umanjenja vrijednosti imovinskih stavki stalnih sredstava, zaliha i kratkotrajnih potraživanja. Rezultati istraživanja pokazuju da računovodstvene manipulacije kod poduzeća u Federaciji BiH u najvećem broju proizlaze iz precijenjenih imovinskih stavki te posljedično podcijenjenih rashoda kao elementa financijske uspješnosti. Na kraju, pokazuje se da se računovodstvene manipulacije u najvećem broju slučajeva manifestiraju u vidu precijenjenog financijskog rezultata (iskazana veća dobit ili manji gubitak od realnog).

S ciljem utvrđivanja tradicionalnih pokazatelja analize financijskih izvještaja koji mogu biti korisni u utvrđivanju računovodstvenih manipulacija u financijskim izvještajima poduzeća izvršeno je testiranje razlika u prosječnim vrijednostima pokazatelja primjenom neparametrijskih testova. Tablica 4. pokazuje da je neparametrijski Mann-Whitney U test na planiranoj razini značajnosti od 5\% (posebno su istaknuti i rezultati na razini značajnosti od 1\%) identificirao 14 tradicionalnih pokazatelja analize financijskih izvještaja koji se razlikuju između poduzeća sa značajnim pogrešnim prikazivanjem i poduzeća bez značajnih pogreška u financijskim izvještajima. $\mathrm{S}$ druge strane, parametrijski T-test na planiranoj razini značajnosti od 5\% identificirao je 12 tradicionalnih pokazatelja koji se razlikuju između dvije promatrane skupine poduzeća.

U pogledu testiranja razlika u tradicionalnim pokazateljima između dvije skupine promatranih poduzeća, rezultati provedenog Mann-Whitney U testa (vidjeti Tablicu 4.) pokazuju da na razini značajnosti od $5 \%$ postoji statistički značajna razlika kod svih skupina tradicionalnih pokazatelja analize financijskih izvještaja, odnosno da iz svake skupine postoji barem po jedan pokazatelj kod kojeg je utvrđena statistički značajna razlika između dvije skupine promatranih poduzeća. Prema tome, utvrđeni tradicionalni pokazatelji analize financijskih izvještaja koji se temelje na obračunskoj osnovi pokazatelji mogu biti koristan instrument za utvrđivanje računovodstvenih manipulacija u financijskim izvještajima poduzeća. 
Tablica 4. Rezultati testova razlika kod tradicionalnih pokazatelja analize financijskih izvještaja u pogledu računovodstvenih manipulacija

\begin{tabular}{|c|c|c|c|c|c|}
\hline \multirow{2}{*}{$\begin{array}{l}\text { Red. } \\
\text { Br. }\end{array}$} & \multirow{2}{*}{$\begin{array}{l}\text { Naziv tradicionalnog poka- } \\
\text { zatelja }\end{array}$} & \multirow{2}{*}{ Oznaka } & $\begin{array}{l}\text { Mann-Whit- } \\
\text { ney test }\end{array}$ & T-test & \multirow{2}{*}{$\begin{array}{l}\text { Sig. ra- } \\
\text { zlika po } \\
\text { oba testa }\end{array}$} \\
\hline & & & Sig. & Sig. & \\
\hline 1. & $\begin{array}{l}\text { Koeficijent ubrzane likvid- } \\
\text { nosti }\end{array}$ & QLiq & $0,003^{*}$ & $0,049 * *$ & DA \\
\hline 2. & $\begin{array}{l}\text { Faktor zaduženosti - broj } \\
\text { godina }\end{array}$ & FqSol & $0,003^{*}$ & $0,045 * *$ & DA \\
\hline 3. & Pokriće troškova kamata & CovInt & $0,023 * *$ & 0,801 & $\mathrm{NE}$ \\
\hline 4. & Stupanj zaduženosti & QSol & 0,080 & $0,056^{* *}$ & NE \\
\hline 5. & $\begin{array}{l}\text { Koeficijent obrtaja tekuće } \\
\text { imovine }\end{array}$ & QtCA & $0,036^{* *}$ & $0,047 * *$ & DA \\
\hline 6. & Trajanje naplate potraživanja & DRec & $0,012 * *$ & $0,017 * *$ & $\mathrm{DA}$ \\
\hline 7. & $\begin{array}{l}\text { Koeficijent obrtaja ukupne } \\
\text { imovine }\end{array}$ & QtTA & $0,056^{* *}$ & $0,015^{* *}$ & DA \\
\hline 8. & Koeficijent obrtaja zaliha & OtInv & 0,634 & $0,007 *$ & NE \\
\hline 9. & Neto marža profita & NmProf & $0,026 * *$ & 0,249 & $\mathrm{NE}$ \\
\hline 10. & Bruto marža profita & BmProf & $0,020 * *$ & 0,173 & $\mathrm{NE}$ \\
\hline 11. & Neto rentabilnost imovine & NmTA & $0,012 * *$ & 0,180 & NE \\
\hline 12. & Bruto rentabilnost imovine & BmTA & $0,011 * *$ & 0,181 & NE \\
\hline 13. & Rentabilnost kapitala & NmCap & $0,015^{* *}$ & 0,062 & $\mathrm{NE}$ \\
\hline 14. & $\begin{array}{l}\text { Koeficijent ukupne ekono- } \\
\text { mičnosti }\end{array}$ & Tec & $0,013 * *$ & 0,093 & NE \\
\hline 15. & $\begin{array}{l}\text { Koeficijent ekonomičnosti } \\
\text { prodaje }\end{array}$ & $\mathrm{Sec}$ & 0,085 & $0,023 * *$ & NE \\
\hline 16. & $\begin{array}{l}\text { Koeficijent ekonomičnosti } \\
\text { financiranja }\end{array}$ & $\mathrm{Fec}$ & 0,888 & $0,048 * *$ & NE \\
\hline 17. & Dobit po dionici & EPS & $0,007 *$ & $0,011 *$ & DA \\
\hline 18. & Odnos zarade i cijene & $\mathrm{E} / \mathrm{P}$ & $0,002^{*}$ & $0,038 * *$ & DA \\
\hline 19. & $\begin{array}{l}\text { Dividendna rentabilnost di- } \\
\text { onice }\end{array}$ & $\mathrm{D} / \mathrm{PPS}$ & 0,241 & $0,054 * *$ & $\mathrm{NE}$ \\
\hline
\end{tabular}

*razina značajnosti od 0,01

**razina značajnosti od 0,05

Izvor: Rezultati istraživanja (N=257); SPSS v. 20

S druge strane, proveden je i parametrijski T-test za potrebe testiranja značajnosti razlika u aritmetičkoj sredini kod svih tradicionalnih pokazatelja analize financijskih izvještaja uključenih $u$ analizu. Rezultati predočeni u Tablici 4. pokazuju da na razini značajnosti od 5\% postoji statistički značajna razlika kod svih skupina 
tradicionalnih pokazatelja analize financijskih izvještaja, izuzev kod pokazatelja profitabilnosti, između poduzeća sa utvrđenim računovodstvenim manipulacijama u financijskim izvještajima i poduzeća bez utvrđenih računovodstvenih manipulacija u financijskim izvještajima. Nadalje, valja ukazati na one pokazatelje koji se statistički značajno razlikuju prema oba testa (parametrijskom i neparametrijskom), a to su: koeficijent trenutne likvidnosti (QLiq), faktor zaduženosti - broj godina (FqSol), koeficijent obrtaja ukupne imovine (QtTA), koeficijent obrtaja tekuće imovine (QtCA), trajanje naplate potraživanja (DRec), dobit po dionici (EPS) i pokazatelj odnosa zarade i cijene (E/P). Rezultati provedenih testova pokazuju da tradicionalni pokazatelji analize financijskih mogu biti koristan indikator za utvrđivanje značajnih pogrešnih prikazivanja u financijskim izvještajima poduzeća.

Jedan od ciljeva ovog rada je analiza obilježja vrijednosti utvrđenih pokazatelja s obzirom na razinu kvalitete financijskih izvještaja poduzeća u Federaciji BiH. Ova analiza je posebice interesantna i korisna kod onih tradicionalnih pokazatelja analize financijskih izvještaja kod kojih su utvrđene razlike na statistički značajnoj razini po oba testa, između poduzeća sa utvrđenim računovodstvenim manipulacijama i bez utvrđenih računovodstvenih manipulacija u financijskim izvještajima. Jedna od polaznih postavki ovog rada je da poduzeća sa utvrđenim računovodstvenim manipulacijama u financijskim izvještajima imaju slabije vrijednosti tradicionalnih pokazatelja analize financijskih izvještaja u odnosu na poduzeća bez računovodstvenih manipulacija u financijskim izvještajima.

Primjerna testova razlika u ovom istraživanju rezultirala je utvrđivanjem koeficijenta trenutne likvidnosti (QLiq) kao pokazatelja likvidnosti koji se značajno razlikuje između dvije promatrane skupine poduzeća s obzirom na utvrđenu razinu računovodstvenih manipulacija u financijskim izvještajima. Rezultati prezentirani u Prilogu 3. pokazuje da poduzeća čiji financijski izvještaji ne sadrže utvrđene računovodstvene manipulacije imaju bolje srednje (prosječne) vrijednosti pokazatelja trenutne likvidnosti (QLiq) u odnosu na poduzeća čiji financijski izvještaje sadrže utvrđena računovodstvene manipulacije. Naime, pokazuje se da poduzeća bez utvrđenih računovodstvenih manipulacija $u$ financijskim izvještajima $u$ prosjeku imaju raspoloživih novčanih sredstava za pokriće 57,78\% svih iskazanih kratkoročnih obveza na datum bilance. S druge strane, poduzeća u čijim su financijskim izvještajima utvrđene računovodstvene manipulacije imaju dvostruko „slabiju“ vrijednost pokazatelja trenutne likvidnosti s obzirom da imaju raspoloživih novčanih sredstava za pokriće $28,06 \%$ iskazanih kratkoročnih obveza na datum bilance. Rezultati pokazuju da su poduzeća čiji financijski izvještaji ne sadrže utvrđene računovodstvene manipulacije likvidnija u odnosu na poduzeća sa utvrđenim računovodstvenim manipulacijama u financijskim izvještajima. Rezultati ovog istraživanja su u skladu s nalazima drugih sličnih istraživanja u vezi 
pokazatelja likvidnosti. Naime, Omoye i Eraghbe $(2014,206-215)$ su pokazali da su pokazatelji likvidnosti povezani s prijevarama u financijskim izvještajima, te se sugerira investitorima i regulatornim tijelima upotreba financijskih pokazatelja kod procjene rizika prijevare $\mathrm{u}$ financijskim izvještajima.

Tradicionalni pokazatelji zaduženosti ukazuju na strukturu izvora sredstava poduzeća. Faktor zaduženost - broj godina (FqSol) je tradicionalni pokazatelj zaduženosti koji se temelji na obračunskoj osnovi a kod kojeg su prethodno provedeni testovi razlika pokazali da se prosječna vrijednost navedenog pokazatelja razlikuje između dvije promatrane skupine poduzeća s obzirom na kvalitetu financijskih izvještaja, na statistički značajnoj razini od 5\%. Rezultati prikazani u Prilogu 3. pokazuju da poduzeća čiji financijski izvještaji ne sadrže računovodstvene manipulacije imaju bolje srednje (prosječne) vrijednosti pokazatelja faktor zaduženost - broj godina (FqSol) u odnosu na poduzeća čiji financijski izvještaje sadrže utvrđene računovodstvene manipulacije. Naime, poduzećima sa utvrđenim računovodstvenim manipulacijama u financijskim izvještajima treba u prosjeku 12,74 godina da podmire svoje obveze iz akumulirane dobiti i amortizacije, dok poduzećima bez utvrđenih računovodstvenih manipulacija u financijskim izvještajima treba nešto manje, odnosno prosječno 8,60 godina. Rezultati ovog istraživanja su u skladu s nalazima drugih istraživanja u vezi pokazatelja zaduženosti. Prema Healyju i Palepu $(2001,419)$ menadžeri zaduženih poduzeća češće odabiru računovodstvene politike koje im omogućavaju manipuliranje uspješnošću poslovanja, nego li menadžeri u poduzećima koja nisu zadužena. Razloge treba tražiti u motivima da se „uljepšanim“ pokazateljima zaduženosti ukaže na veću kreditnu sposobnost radi lakšeg dolaska do dodatnih izvora financiranja. S druge strane Richardson et al. (2002, 1-41) su utvrdili da poduzeća, koja su pogrešno prezentirala uspješnost poslovanja (zarade) u financijskim izvještajima, imala su visok udio duga u financiranju. U skladu s postavkama ovog rada, pokazuje se da poduzeća sa utvrđenim računovodstvenim manipulacijama u financijskim izvještajima u prosjeku imaju ,slabije“ vrijednosti tradicionalnih pokazatelja zaduženosti u odnosu poduzeća bez utvrđenih računovodstvenih manipulacija u financijskim izvještajima poduzeća.

Prethodna istraživanja ukazuju na to da pokazatelji aktivnosti mogu biti koristan instrument u procjeni kvalitete financijskih izvještaja. Tako je jedan od ključnih diskriminacijskih faktora u Beneishovu M-modelu pokazatelj trajanja naplate potraživanja (1999, 24-36). S druge strane, Skousen et al. (2008, 1-39) pokazali su da, između ostalog, brzi rast imovine, pozitivno utječe na vjerojatnost pojave prijevara, odnosno namjernih značajnih pogrešnih prikazivanja u financijskim izvještajima. Primjerna testova razlika u ovom istraživanju rezultirala je utvrđivanjem čak tri pokazatelja iz skupine pokazatelja aktivnosti koji se značajno razlikuje između dvije promatrane skupine poduzeća s obzirom na kvalitetu financijskih 
izvještaja. To su: koeficijent obrtaja imovine (QtTA), koeficijent obrtaja kratkotrajne imovine (QtCA) i trajanje naplate potraživanja (DRec). Rezultati analize tradicionalnih pokazatelja aktivnosti prikazani (vidjeti Prilog 3.) pokazuju da poduzeća čiji financijski izvještaji ne sadrže računovodstvene manipulacije u pravilu imaju bolje srednje (prosječne) vrijednosti pokazatelja obrtaja imovine i kratkotrajne imovine u odnosu na poduzeća čiji financijski izvještaje sadrže utvrđene računovodstvene manipulacije. Kada se raspravlja o referentnim vrijednostima kod pokazatelja aktivnosti teži se maksimalizaciji istih izuzev kod pokazatelja dani naplate potraživanja gdje se teži minimalizaciji istih kako bi se efikasnost upotrebe imovine dovela na najveću moguću razinu. Interesantno je primijetiti da poduzećima sa računovodstvenim manipulacijama u financijskim izvještajima treba u prosjeku 151 dan kako bi naplatili svoja kratkotrajna potraživanja što je za oko $50 \%$ dulje u odnosu na poduzeća bez računovodstvenih manipulacija kojima u prosjeku naplata kratkotrajnih potraživanja traje 105 dana. Rezultati pokazuju da su poduzeća čiji financijski izvještaji ne sadrže utvrđene računovodstvene manipulacije aktivnija i bolje i efikasnije koriste svoju imovinu u odnosu na poduzeća sa utvrđenim računovodstvenim manipulacijama u financijskim izvještajima. Rezultati su očekivani ukoliko se ima na umu da su prethodno kao najčešća područja značajnih pogrešnih prikazivanja identificirana vrijednosna usklađenja potraživanja i umanjenja zaliha. Stoga je logično da i pokazatelji koji se odnose na ta područja budu koristan indikator u utvrđivanju značajnih pogrešnih prikazivanja u financijskim izvještajima i razlikovanju poduzeća u ovisnosti od kvalitete prezentiranih financijskih izvještaja.

Dobit po dionici (EPS) i odnos zarade i cijene (E/P) su tradicionalni pokazatelji investiranja koji se temelje na obračunskoj osnovi, a kod kojih su prethodno provedeni testovi razlika pokazali da se prosječna vrijednost navedenih pokazatelja razlikuje između dvije promatrane skupine poduzeća s obzirom na kvalitetu financijskih izvještaja, na statistički značajnoj razini. U pogledu analize pokazatelja investiranja, rezultati prezentirani u Prilogu 3. ukazuju da poduzeća bez računovodstvenih manipulacija u financijskim izvještajima imaju pozitivnu vrijednost ostvarene dobiti po dionici koja se kreće u prosjeku na razini od 0,92 KM po dionici. S druge strane predmetni pokazatelj kod poduzeća sa računovodstvenim manipulacijama imaju nepovoljnu prosječno negativnu vrijednost dobiti po dionici, što je i logično budući da se prethodno pokazalo da predmetna poduzeća u prosjeku posluju s negativnim rezultatom poslovanja. Ranija istraživanja su ukazala na korisnost pokazatelja investiranja u procjeni kvalitete financijskih izvještaja. Omoye i Eraghbe $(2014,206-215)$ su pokazali da su pokazatelji investiranja povezani s prijevarama u financijskim izvještajima. S druge strane, Dechow et al. (2010, 1-68) su utvrdili da poduzeća sa značajnim pogrešnim prikazivanjem u financijskim izvještajima između ostalog imaju veće vrijednosti pokazatelja investiranja 
Na kraju, u skladu s postavkama ovog rada, pokazuje se da poduzeća sa utvrđenim računovodstvenim manipulacijama $u$ financijskim izvještajima u prosjeku imaju „slabije“ vrijednosti tradicionalnih pokazatelja investiranja u odnosu poduzeća bez utvrđenih računovodstvenih manipulacija u financijskim izvještajima poduzeća.

\section{ZAKLJUČAK}

Postizanje maksimalne informacijske korisnosti financijskih izvještaja je jedan od osnovnih ciljeva procesa financijskog izvještavanja. Neophodan preduvjet za realizaciju tog cilja su realno i objektivno prezentirani financijski izvještaji odnosno financijski izvještaji bez računovodstvenih manipulacija.

Rezultati ovog istraživanja su pokazala da se najčešća područja značajnih pogrešnih prikazivanja u financijskim izvještajima poduzeća u Federaciji BiH odnose na stavke vrijednosnih usklađenja kratkotrajnih potraživanja i umanjenja vrijednosti stalnih sredstava i zaliha. Nadalje, rezultati provedenog istraživanja ukazuju da tradicionalni pokazatelji analize financijskih izvještaja koji se temelje na obračunskoj osnovi pozitivno utječu na utvrđivanje računovodstvenih manipulacija u financijskim izvještajima poduzeća. Naime, provedeni testovi razlika pokazali su da su kod svih skupina tradicionalnih pokazatelja analize financijskih izvještaja, odnosno barem kod jednog pokazatelja u okviru svake skupine tradicionalnih pokazatelja, postoji razlika na statistički značajnoj razini od 5\% između poduzeća sa utvrđenim računovodstvenim manipulacijama u financijskim izvještajima i poduzeća bez utvrđenih računovodstvenih manipulacija u financijskim izvještajima. Prema tome, utvrđeni tradicionalni pokazatelji analize financijskih izvještaja koji se temelje na obračunskoj osnovi pozitivno utječu na utvrđivanje računovodstvenih manipulacija $u$ financijskim izvještajima poduzeća. Nadalje, u skladu s ciljevima ovog rada, pokazuje se da poduzeća sa utvrđenim računovodstvenim manipulacijama u financijskim izvještajima u prosjeku imaju „slabije“ vrijednosti tradicionalnih pokazatelja u odnosu poduzeća bez utvrđenih računovodstvenih manipulacija $u$ financijskim izvještajima poduzeća. Može se zaključiti da tradicionalni pokazatelji analize financijskih izvještaja koji se temelje na obračunskoj osnovi predstavljaju koristan instrument u utvrđivanju računovodstvenih manipulacija u financijskim izvještajima poduzeća.

Pri ocjeni rezultata predmetnog istraživanja u pogledu utjecaja tradicionalnih pokazatelja analize financijskih izvještaja na utvrđivanje računovodstvenih manipulacija $u$ financijskim izvještajima poduzeća, treba uzeti u obzir ograničenje istraživanja a koje proizlazi iz činjenice da je zaključak opravdan uz pretpostavku da je korištena zavisna varijabla, u pogledu vrste revizorovog mišljenja, dobra 
mjera postojanja računovodstvenih manipulacija u financijskim izvještajima. Naime, s obzirom na objektivne okolnosti (kao što su postojanje revizijskog rizika koji je neizbježan zahvaljujući inherentnim ograničenjima revizijskog procesa), te subjektivne okolnosti (kao što je ugrožena kvaliteta revizije zbog ugrožene neovisnosti ili upitne stručnosti revizora), vrsta revizorovog mišljenja ne mora biti izravno povezana s postojanjem značajnih pogrešnih prikazivanja u financijskim izvještajima kao posljedica pogreške ili prijevare.

Rezultati ovog istraživanja predstavljaju korisnu spoznaju o razini kvalitete financijskih izvještaja u Federaciji $\mathrm{BiH}$, kao i o obuhvatu i obilježjima vrijednosti tradicionalnih pokazatelja analize financijskih izvještaja koji doprinose utvrđivanju računovodstvenih manipulacija $u$ financijskim izvještajima poduzeća $u$ Federaciji BiH. Doprinos ovog istraživanja ogleda se i u činjenici da će se rezultati moći iskoristiti u funkciji unaprjeđenja procesa financijskog izvještavanja i razine kvalitete financijskih izvještaja u cjelini. U pogledu smjernica za naredna istraživanja, korisno bi bilo istražiti utjecaj tradicionalnih pokazatelja analize financijskih izvještaja na utvrđivanje računovodstvenih manipulacija u financijskim izvještajima po pojedinim djelatnostima. Također, interesantno bi bilo provesti komparativnu analizu utjecaja tradicionalnih pokazatelja analize financijskih izvještaja koji se temelje na obračunskoj osnovi u odnosu na pokazatelje koji se temelje na novčanoj osnovi, na utvrđivanje računovodstvenih manipulacija u financijskim izvještajima poduzeća.

\section{LITERATURA}

1. Altman, E. (2002): Bankruptcy, Credit Risk, and High Yield Junk Bonds. Danvers, Blackwell Publishing

2. Aljinović Barać, Ž., Klepo, T. (2006): Features of accounts manipulations in Croatia, Zbornik radova Ekonomskog fakulteta u Rijeci - Časopis za ekonomsku teoriju i praksu 24, Ekonomski fakultet Rijeka, Rijeka, str. 273-290.

3. Bayley, L.; Taylor, S. (2007): Identifying earnings overstatements: A practical test. Working paper, ABN Amro Sydney and University of New South Wales

4. Belak, V. (1995): Menadžersko računovodstvo, Računovodstvo, revizija i financije - RRiF, Zagreb

5. Beneish, M.D. (1997): Detecting GAAP Violation: Implications for Assessing Earnings Management among Firms with Extreme Financial Performance. Journal of Accounting and Public Policy 16, str. 271-309.

6. Beneish, M.D. (1999): The Detection of Earnings Manipulation, Financial Analyst Journal, str. 24-36. 
7. Cuzdriorean, D.D. (2013): Most recent findings in earnings management area: interesting insights from traditionally top 5 leading accounting journals, Annales Universitatis Apulensis Series Oeconomica, 15(2), str. 402-416.

8. Dechow, P. M., I. Dichev (2002): The quality of accruals and earnings: The role of accrual estimation errors. The Accounting Review 77: str. 35-59.

9. Dechow, Patricia M., Ge, Weili Larson, Chad R. Sloan, Richard G. (2010): Predicting Material Accounting Misstatements. Contemporary Accounting Research, Forthcoming; AAA 2008 Financial Accounting and Reporting Section (FARS) Paper. (SSRN: http://ssrn.com/abstract=997483

10. Elliot, B.; Elliot, J. (2011): Financial Accounting and Reporting, Financial Times Prentice Hall, 14th edition

11. Gibson, H., C. (2011): Financial reporting \& Analysis - using financial accounting information, South Western Cengage Learning, Mason

12. Gulin, D. (2002): Manipulacije na financijskim tržištima i njihov utjecaj na financijske izvještaje, Računovodstvo, financije i revizija u suvremenim gospodarskim uvjetima, XXXVII. simpozij Pula, Zagreb, HZRiF

13. Healy, P. M., Wahlen, J. M. (1999): A Review of the Earnings Management Literature and its Implications for Standard Setting, Accounting Horizons, 13 (4), str. 365-383.

14. Healy, P.M, Palepu K.G. (2001): Information asymmetry, corporate disclosure, and the capital markets: A review of the empirical disclosure literature // Journal of Accounting and Economics, No 31, str. 405-440.

15. Horrigan, J. O. (1965). Some Empirical Bases of Financial Ratio Analysis, The Accounting Review, Vol.40, broj 3, str. 558-568.

16. Jones, J. J. (1991): Earnings management during import relief investigations. Journal of Acounting Research 29, str. 193-228.

17. Jooste, L (2004): An evaluation of the usefulness of the cash flow statement within South African companies by means of cash flow ratios: University of Pretoria

18. Korcan, B., Dechow, P., Yuan, S., Wang, A. (2013): The Use of Financial Ratio Models to Help Investors Predict and Interpret Significant Corporate Events, working paper, http://ssrn.com/abstract=2335185). str. 1-75.

19. Omoye, A.S.; Eragbhe, E. (2014): Accounting ratios and false financial statements detection: evidence from Nigerian quoted companies, International Journal of Business and Social Science 5, str. 206-215.

20. Prevoo, L.J.N. (2007): Detecting earnings management - a critical assessment of the Beneish model, Universiteit Maastricht Faculty of economics and business administration, Maastricht, str. 1-60. 
21. Richardson, S. A., Sloan, R. G., Soliman, M. T., Tuna, A. I. (2006): The Implications of Accounting Distortions and Growth for Accruals and Profitability, The Accounting Review, 81(3), str. 713-741.

22. Richardson, S., Tuna, I., Wu, M. (2002): Predicting earnings management: The case of earnings restatements, working paper, http://papers.ssrn.com/abstract $=338681$, str. 1-41.

23. Ronen, J., Yaari, V. (2008): Earnings Management, Emerging Insights in Theory, Practice, and Research, Springer

24. Savez računovođa, revizora i financijskih djelatnika FBiH (2017): Međunarodni računovodstveni standardi / Međunarodni standardi financijskog izvještavanja (MSFI/MRS), Mostar (http://www.srr-fbih.org/msfimrs-14)

25. Schipper, K. (1989): Commentary on earnings management, Accounting Horizons, Vol. 3, No 4, str. 91-102.

26. Skousen, Christopher J. Smith, Kevin R., Wright, Charlotte J. (2008): Detecting and Predicting Financial Statement Fraud: The Effectiveness of the Fraud Triangle and SAS No. 99 (http://ssrn.com/abstract=1295494)

27. Sloan, R.G. (1996): Do Stock Prices Fully Reflect Information in Accruals and Cash Flows about Future Earnings, The Accounting Review 71, str. 289-315.

28. Vidučić, LJ. (2008): Financijski menadžment, Revizija, računovodstvo i financije - RRiF, Zagreb

29. Warren, C., S.; Reeve, J., M.; Duchac, E., J. (2012): Financial Accounting, South Western Cengage Learning, Mason

30. Žager, L., Žager, K., Mamić Sačer, I., Sever, S. (2008): Analiza financijskih izvještaja, Masmedia, Zagreb 


\title{
ACCRUAL BASED RATIOS IN THE FUNCTION OF DETERMINATION OF ACCOUNTING MANIPULATIONS IN THE FINANCIAL STATEMENTS OF COMPANIES
}

Received: September 6, 2018

Accepted: October 1, 2018

Preliminary communication

\begin{abstract}
The financial statements of general purpose are important source of information for the business decision-making. The subject of this paper is the research of the impact of accrual-based ratios on the determination of accounting manipulations in the financial statements of companies. The main objective is to identify the accrual-based ratios that contribute to the determination of accounting manipulations in the financial statements and an analysis of the value characteristics of identified accrual-based ratios, due to the level of accounting manipulations in the financial statements of companies in the Federation of BiH. The research was conducted on a sample of companies from the capital market in the Federation of $B \& H$ in the period from 2010 to 2014. The collected data were analysed using the descriptive and inferential statistics methods, and obtained results are presented by graphics and tables. The application of parametric and nonparametric statistical tests at a significance level of 5\% resulted in determination of the accrual-based ratios that are significantly different between companies with detected accounting manipulations and companies without detected accounting manipulations in the financial statements. Those ratios are Quick ratio (QLiq), Total debt - the number of years (FqSol), Turnover coefficient of total assets (QtTA), Turnover coefficient of current assets (QtCA), Duration of receivables payment (DRec), Earnings per share (EPS) and Earnings and price ratio (E/P). Research results also indicates that companies with detected accounting manipulations in the financial statements have, on average, "weaker" values of accrual-based ratios in relation to companies without detected accounting manipulations in the financial statements. Thus, it is evident that accrual-based ratios have a positive impact on determination of accounting manipulations in the financial statements of the companies.
\end{abstract}


Keywords: financial statements, accounting manipulations, accrual-based ratios

JEL: M41, M42 
Prilog 1. - Pregled oznaka i načina izračuna tradicionalnih pokazatelja analize financijskih izvještaja

\begin{tabular}{|c|c|c|c|}
\hline Naziv pokazatelja & $\begin{array}{c}\text { Oznaka poka- } \\
\text { zatelja }\end{array}$ & & Opis i način mjerenja \\
\hline \multirow{2}{*}{$\begin{array}{l}\text { Koeficijent } \\
\text { trenutne likvidnosti }\end{array}$} & \multirow{2}{*}{ QLiq } & \multirow{2}{*}{$=$} & Novac \\
\hline & & & Kratkoročne obveze \\
\hline \multirow{2}{*}{$\begin{array}{l}\text { Koeficijent } \\
\text { ubrzane likvidnosti }\end{array}$} & \multirow{2}{*}{ FLiq } & \multirow{2}{*}{$=$} & Novac + Potraživanja \\
\hline & & & Kratkoročne obveze \\
\hline \multirow{2}{*}{$\begin{array}{l}\text { Koeficijent } \\
\text { tekuće likvidnosti }\end{array}$} & \multirow{2}{*}{ CLiq } & \multirow{2}{*}{$=$} & Kratkotrajna imovina \\
\hline & & & Kratkoročne obveze \\
\hline \multirow{2}{*}{$\begin{array}{l}\text { Koeficijent } \\
\text { financijske stabilnosti }\end{array}$} & \multirow{2}{*}{ FSt } & \multirow{2}{*}{$=$} & Dugotrajna imovina \\
\hline & & & Kapital + Dugoročne obveze \\
\hline \multirow{2}{*}{ Koeficijent zaduženosti } & \multirow{2}{*}{ QSol } & \multirow{2}{*}{$=$} & Ukupne obveze \\
\hline & & & Ukupna aktiva \\
\hline \multirow{2}{*}{$\begin{array}{l}\text { Koeficijent vlastitog financi- } \\
\text { ranja }\end{array}$} & \multirow{2}{*}{ QCap } & \multirow{2}{*}{$=$} & Kapital \\
\hline & & & Ukupna aktiva \\
\hline \multirow{2}{*}{ Koeficijent financiranja } & \multirow{2}{*}{ LibCap } & \multirow{2}{*}{$=$} & Ukupne obveze \\
\hline & & & Kapital \\
\hline \multirow{2}{*}{ Faktor zaduženosti } & \multirow{2}{*}{ FqSol } & \multirow{2}{*}{$=$} & Ukupne obveze \\
\hline & & & Zadržana dobit + amortizacija \\
\hline \multirow{2}{*}{ Pokriće troškova kamata } & \multirow{2}{*}{ CovInt } & \multirow{2}{*}{$=$} & Dobit prije kamata i poreza \\
\hline & & & Troškovi kamata \\
\hline \multirow{2}{*}{$\begin{array}{l}\text { Koeficijent } \\
\text { obrtaja imovine }\end{array}$} & \multirow{2}{*}{ QtTA } & \multirow{2}{*}{$=$} & Ukupni prihodi \\
\hline & & & Ukupna imovina \\
\hline \multirow{2}{*}{$\begin{array}{l}\text { Koeficijent obrtaja kratkotrajne } \\
\text { imovine }\end{array}$} & $\mathrm{OtCA}$ & $=$ & Ukupni prihodi \\
\hline & & & Kratkotrajna imovina \\
\hline Koeficijent & OtRec & $=$ & Prihodi od prodaje \\
\hline obrtaja potraživanja & & & Potraživanja od prodaje \\
\hline Koeficijent & OtIny & $=$ & Troškovi za prodano \\
\hline obrtaja zaliha & Q Liniv & & Zalihe \\
\hline Traianie nanlate notraživania & $\mathrm{DRec}$ & $=$ & 365 dana \\
\hline & & & Obrtaj potraživanja (QtRec) \\
\hline Dani vezivanis zalihs & DIny & $=$ & 365 dana \\
\hline DanI vezivanja Zanmia & Dimv & - & Obrtaj zaliha (QtInv) \\
\hline Neto marža profita & NmProf & $=$ & Neto dobit + kamate \\
\hline Tetr inalza pivita & & & Ukupni prihodi \\
\hline
\end{tabular}


Dragan Gabrić

\begin{tabular}{|c|c|c|c|}
\hline \multirow{2}{*}{ Bruto marža profita } & \multirow{2}{*}{ BmProf } & \multirow{2}{*}{$=$} & Dobit prije kamata i poreza \\
\hline & & & Ukupni prihodi \\
\hline \multirow{2}{*}{ Neto rentabilnost imovine } & \multirow{2}{*}{ NmTA } & \multirow{2}{*}{$=$} & Neto dobit + kamate \\
\hline & & & Ukupna imovina \\
\hline \multirow{2}{*}{ Bruto rentabilnost imovine } & \multirow{2}{*}{ BmTA } & \multirow{2}{*}{$=$} & Dobit prije kamata i poreza \\
\hline & & & Ukupna imovina \\
\hline \multirow{2}{*}{ Rentabilnost kapitala } & \multirow{2}{*}{ NmCap } & \multirow{2}{*}{$=$} & Neto dobit \\
\hline & & & Kapital \\
\hline \multirow{2}{*}{$\begin{array}{l}\text { Koeficijent } \\
\text { ukupne ekonomičnosti }\end{array}$} & \multirow{2}{*}{ Tec } & \multirow{2}{*}{$=$} & Ukupni prihodi \\
\hline & & & Ukupni rashodi \\
\hline \multirow{2}{*}{$\begin{array}{l}\text { Koeficijent } \\
\text { ekonomičnosti prodaje }\end{array}$} & \multirow{2}{*}{$\mathrm{Sec}$} & \multirow{2}{*}{$=$} & Prihodi od prodaje \\
\hline & & & Troškovi za prodano \\
\hline \multirow{2}{*}{$\begin{array}{l}\text { Koeficijent } \\
\text { ekonomičnosti financiranja }\end{array}$} & \multirow{2}{*}{ Fec } & \multirow{2}{*}{$=$} & Financijski prihodi \\
\hline & & & Financijski rashodi \\
\hline \multirow{2}{*}{ Dobit po dionici } & \multirow{2}{*}{ EPS } & \multirow[b]{2}{*}{$=$} & Neto dobit \\
\hline & & & Prosječan broj dionica \\
\hline \multirow{2}{*}{$\begin{array}{l}\text { Dividenda } \\
\text { po dionici }\end{array}$} & \multirow{2}{*}{ DPS } & \multirow{2}{*}{$=$} & Neto dobiti za isplatu \\
\hline & & & Prosječan broj dionica \\
\hline \multirow{2}{*}{ Odnos cijene i zarade } & \multirow{2}{*}{$\mathrm{P} / \mathrm{E}$} & \multirow{2}{*}{$=$} & Tržišna cijena dionice \\
\hline & & & Dobit po dionici \\
\hline \multirow{2}{*}{ Odnos isplate dividendi } & \multirow{2}{*}{$\mathrm{D} / \mathrm{EPS}$} & \multirow{2}{*}{$=$} & Dividenda po dionici \\
\hline & & & Dobit po dionici \\
\hline \multirow{2}{*}{ Ukupna rentabilnost dionice } & $\mathrm{F} / \mathrm{P}$ & $=$ & Dobit po dionici \\
\hline & $\mathrm{E} / \mathrm{P}$ & $=$ & Tržišna cijena dionice \\
\hline Dividendna rentabilnost dio- & $\mathrm{D} / \mathrm{P}$ & $=$ & Dividenda po dionici \\
\hline nice & D/PS & - & Tržišna cijena dionice \\
\hline
\end{tabular}

Izvor: Žager et al., 2008, 243-296. 
Prilog 2. - Rezultati testova razlika i grupne statistike za stalna sredstva, zalihe i kratkotrajna potraživanja

\begin{tabular}{|c|c|c|c|c|c|c|}
\hline Stavka & $\begin{array}{c}\text { Mann- } \\
\text { Whitney } \\
\text { Test / } \\
\text { Sig. }\end{array}$ & $\begin{array}{c}\text { T-test } \\
\text { Sig. }\end{array}$ & $\begin{array}{l}\text { Sig. razlika } \\
\text { po oba } \\
\text { testa }\end{array}$ & $\mathrm{AC}$ & $\mathrm{N}$ & $\begin{array}{c}\text { Srednja } \\
\text { vrijednost }\end{array}$ \\
\hline \multirow{2}{*}{$\begin{array}{l}\text { Stalna } \\
\text { sredstva } \\
(\mathrm{NCA})\end{array}$} & \multirow{2}{*}{$0,000^{*}$} & \multirow{2}{*}{$0,001 *$} & \multirow{2}{*}{ DA } & $\begin{array}{l}\text { Pozitivno } \\
\text { revizorsko } \\
\text { mišljenje }\end{array}$ & 162 & 56.017 .235 \\
\hline & & & & $\begin{array}{l}\text { Modificirano } \\
\text { revizorsko } \\
\text { mišljenje }\end{array}$ & 95 & 249.314 .641 \\
\hline \multirow{2}{*}{ Zalihe (Inv) } & \multirow{2}{*}{$0,000^{*}$} & \multirow{2}{*}{$0,001^{*}$} & \multirow{2}{*}{ DA } & $\begin{array}{l}\text { Pozitivno } \\
\text { revizorsko } \\
\text { mišljenje }\end{array}$ & 162 & 3.412 .316 \\
\hline & & & & $\begin{array}{l}\text { Modificirano } \\
\text { revizorsko } \\
\text { mišljenje }\end{array}$ & 95 & 11.516 .061 \\
\hline \multirow{2}{*}{$\begin{array}{l}\text { Kratkotrajna } \\
\text { potraživanja } \\
(\mathrm{SRec})\end{array}$} & \multirow{2}{*}{$0,004 *$} & \multirow{2}{*}{$0,001 *$} & \multirow{2}{*}{ DA } & $\begin{array}{l}\text { Pozitivno } \\
\text { revizorsko } \\
\text { mišljenje }\end{array}$ & 162 & 7.400 .105 \\
\hline & & & & $\begin{array}{l}\text { Modificirano } \\
\text { revizorsko } \\
\text { mišljenje }\end{array}$ & 95 & 19.258 .821 \\
\hline
\end{tabular}

Izvor: Rezultati istraživanja (N=257); SPSS v.20; *razina značajnosti od 0,01 
Prilog 3. - Analiza tradicionalnih pokazatelja analize financijskih izvještaja prema računovodstvenim manipulacijama

\begin{tabular}{|c|c|c|c|c|c|c|c|c|}
\hline \multicolumn{2}{|c|}{$\begin{array}{l}\text { Stanje računovodstvenih } \\
\text { manipulacija }\end{array}$} & QLiq & FqSol & QtTA & QtCA & DRec & EPS & $\mathrm{E} / \mathrm{P}$ \\
\hline \multirow{5}{*}{$\begin{array}{l}\text { Pozitivno } \\
\text { revizorsko } \\
\text { mišljenje }\end{array}$} & $\mathrm{N}$ & 158 & 145 & 157 & 154 & 127 & 133 & 101 \\
\hline & $\begin{array}{l}\text { Srednja vri- } \\
\text { jednost }\end{array}$ & 0,5778 & 8,6060 & 0,5798 & 2,3791 & 104,8815 & 0,9221 & 0,0434 \\
\hline & Medijan & 0,0646 & 3,3295 & 0,4286 & 1,9734 & 77,6247 & 0,2621 & 0,0000 \\
\hline & $\begin{array}{l}\text { Std. devija- } \\
\text { cija }\end{array}$ & 1,2822 & 13,8834 & 0,5957 & 1,9166 & 113,2494 & 3,6589 & 0,1820 \\
\hline & $\begin{array}{l}\% \text { od uku- } \\
\text { pno }\end{array}$ & $64,0 \%$ & $60,9 \%$ & $62,3 \%$ & $62,3 \%$ & $58,8 \%$ & $61,0 \%$ & $57,7 \%$ \\
\hline \multirow{5}{*}{$\begin{array}{l}\text { Modificirano } \\
\text { revizorsko } \\
\text { mišljenje }\end{array}$} & $\mathrm{N}$ & 89 & 93 & 95 & 93 & 89 & 85 & 74 \\
\hline & $\begin{array}{l}\text { Srednja vri- } \\
\text { jednost }\end{array}$ & 0,2806 & 12,7411 & 0,4096 & 1,9167 & 151,0825 & $-0,2771$ & 0,0024 \\
\hline & Medijan & 0,0267 & 4,6948 & 0,3063 & 1,7299 & 100,9965 & 0,0145 & 0,0000 \\
\hline & $\begin{array}{l}\text { Std. devija- } \\
\text { cija }\end{array}$ & 0,8004 & 17,6109 & 0,4162 & 1,4832 & 167,9728 & 2,7873 & 0,0082 \\
\hline & $\begin{array}{l}\% \text { od uku- } \\
\text { pno }\end{array}$ & $36,0 \%$ & $39,1 \%$ & $37,7 \%$ & $37,7 \%$ & $41,2 \%$ & $39,0 \%$ & $42,3 \%$ \\
\hline \multirow{5}{*}{ Ukupno } & $\mathrm{N}$ & 247 & 238 & 252 & 247 & 216 & 218 & 175 \\
\hline & $\begin{array}{l}\text { Srednja vri- } \\
\text { jednost }\end{array}$ & 0,4707 & 10,2218 & 0,5156 & 2,2050 & 123,9180 & 0,4545 & 0,0261 \\
\hline & Medijan & 0,0488 & 3,9029 & 0,3674 & 1,8798 & 86,0386 & 0,0450 & 0,0000 \\
\hline & $\begin{array}{l}\text { Std. devija- } \\
\text { cija }\end{array}$ & 1,1397 & 15,5433 & 0,5406 & 1,7770 & 139,9437 & 3,3904 & 0,1396 \\
\hline & $\begin{array}{l}\% \text { od uku- } \\
\text { pno }\end{array}$ & $100,0 \%$ & $100,0 \%$ & $100,0 \%$ & $100,0 \%$ & $100,0 \%$ & $100,0 \%$ & $100,0 \%$ \\
\hline
\end{tabular}

Izvor: Rezultati istraživanja (N=257); SPSS v.20 